\author{
N. M. Smielova, O. A. Yevtifieieva, S. M. Gubar \\ National University of Pharmacy
}

\title{
THE ASSESSMENT OF THE QUALITY PARAMETERS OF INULIN ACTIVE PHARMACEUTICAL INGREDIENTS ACCORDING TO PHYSICOCHEMICAL CHARACTERISTICS
}

Aim. To assess the quality parameters of plant active pharmaceutical ingredients (API) in accordance with the requirements of modern normative documents by such physicochemical characteristics as "Description", "Solubility", "Hygroscopy", "Microscopy", as well as identification of the structural components of fructan in order to involve the data obtained in development of the national normative documents on the substance of inulin.

Results. The study of nine plant API of inulin obtained from chicory, agave and Jerusalem artichoke, as well as the reference standards of fructan from chicory and dahlia has been conducted by such physicochemical characteristics as "Description", "Solubility", "Hygroscopy" "Microscopy". According to the British Pharmacopoeia 2010 (BP) the chemical reactions of identification confirmed the presence of fructose and glucose after hydrolysis of the substance. According to the United States Pharmacopeia 36 - NF 31 (USP) it has been found by the identification reaction that the substances analyzed (in addition to the standard substances) contain impurities of sugars with the properties of reducing agents. By appearance the samples under study are loose, amorphous powders of practically white and pale yellow color, they are hygroscopic and very hygroscopic, readily soluble and very soluble in hot water. By the microscopic study they are completely or partially fragmented spherical or ovoid fractions with the expressed central micelles and peripheral semi-transparent shells, as well as small parts separated from the main pseudocrystalline formations.

Conclusions. The results of studying the substances of inulin by such physicochemical characteristics as "Description", "Solubility", "Hygroscopy", "Microscopy", as well as identification of the structural components of fructan according to the requirements of the BP and USP, can be used for the input quality control of plant API of inulin to confirm the structure and determine the purity of the substance. The results of studying the physicochemical characteristics of plant API of inulin can be used when developing the national normative documents on the substance of inulin.

Key words: inulin; description; solubility; hygroscopy; microscopy; identification; quality control

\section{Н. М. СмєЛова, О. А. ЄвтіФєєва, С. М. ГуваРь}

\section{ОЦІНКА ПОКАЗНИКІВ ЯКОСТІ АКТИВНОГО ФАРМАЦЕВТИЧНОГО ІНГРЕДІЕНТА ІНУЛІНУ ЗА ФІЗИКО-ХІМІЧНИМИ ХАРАКТЕРИСТИКАМИ}

Метою роботи є оцінка показників якості рослинних активних фармацевтичних інгредієнтів інуліну згідно з вимогами сучасної нормативної документації за такими фізико-хімічними характеристиками як «Опис», «Розчинність», «Гігроскопічність», «Мікроскопія», а також ідентифікація структурних складових фруктану з метою залучення одержаних даних при розробці національної нормативної документації на субстанцію інуліну.

Результати. Проведено дослідження дев’яти рослинних АФІ інуліну, одержаних з цикорію, агави та топінамбуру, а також стандартних зразків фруктану з цикорію та жоржини за фізико-хімічними характеристиками «Опис», «Розчинність», «Гігроскопічність», «Мікроскопія». Хімічними реакціями ідентифікації згідно з Британською фармакопеєю 2010 підтверджено наявність фруктози та глюкози після гідролізу субстанції. За реакцією ідентифікації за Американською фармакопеєю 36 - NF 31 встановлено, що аналізовані сполуки (окрім стандартних речовин) містять домішки цукрів, що мають властивості відновників. За зовнішнім виглядом наведені зразки представляють собою сипкі, аморфні порошки білого, майже білого та блідожовтого кольору, гігроскопічні та дуже гігроскопічні, легко та дуже легко розчинні у гарячій воді. За мікроскопічним дослідженням - це повністю або частково фрагментовані сферичні чи яйцеподібні частки, для яких виражені центральні міцели і периферичні напівпрозорі оболонки, а також невеликі частки, що відділяються від основних псевдокристалічних утворень.

Висновки. Результати дослідження субстанцій інуліну за такими фізико-хімічними характеристиками як «Опис», «Розчинність», «Гігроскопічність», «Мікроскопія», а також ідентифікація структурних складових фруктану за вимогами Британської та Американської фармакопей можуть бути використані для вхідного контролю якості рослинних активних фармацевтич- 
них інгредієнтів інуліну як для підтвердження структури, так і з метою визначення чистоти субстанції. Результати вивчення фізико-хімічних характеристик рослинних активних фармацевтичних інгредієнтів інуліну можуть бути використані при розробці національної нормативної документації на субстанцію інуліну.

Ключові слова: інулін; опис; розчинність; гігроскопічність; мікроскопія; ідентифікація; контроль якості

\section{Н. Н. Смелова, О. А. ЕвтИФЕева, С. Н. Губарь \\ ОЦЕНКА ПОКАЗАТЕЛЕЙ КАЧЕСТВА АКТИВНОГО ФАРМАЦЕВТИЧЕСКОГО ИНГРЕДИЕНТА ИНУЛИНА ПО ФИЗИКО-ХИМИЧЕСКИМ ХАРАКТЕРИСТИКАМ}

Целью работы является оценка показателей качества растительных АФИ инулина согласно требованиям современной нормативной документации по таким физико-химическим характеристикам как «Описание», «Растворимость», «Гигроскопичность», «Микроскопия», а также идентификация структурных составляющих фруктана с целью привлечения полученных данных при разработке национальной нормативной документации на субстанцию инулин.

Результаты. Проведено исследование девяти растительных АФИ инулина, полученных из цикория, агавы и топинамбура, а также стандартных образцов фруктана из цикория и георгины по физико-химическим характеристикам «Описание», «Растворимость», «Гигроскопичность», «Микроскопия». Химическими реакциями идентификации согласно Британской фармакопее 2010 подтверждено наличие фруктозы и глюкозы после гидролиза субстанции. По реакции идентификации согласно Американской фармакопее 36 - NF 31 установлено, что рассматриваемые соединения (кроме стандартных веществ) содержат примеси сахаров, обладающие свойствами восстановителей. По внешнему виду приведенные образцы представляют собой сыпучие, аморфные порошки белого, почти белого и бледно-желтого цвета, гигроскопичны и очень гигроскопичны, легко и очень легко растворимые в горячей воде. По результатам микроскопических исследований - это полностью или частично фрагментированные сферические или яйцевидные частицы, для которых выражены центральные мицеллы и периферические полупрозрачные оболочки, а также небольшие частицы, отделяющиеся от основных псевдокристаллических образований.

Выводы. Результаты исследования субстанций инулина по таким физико-химическим характеристикам как «Описание», «Растворимость», «Гигроскопичность», «Микроскопия», а также идентификация структурных составляющих фруктана по требованиям Британской и Американской фармакопей могут быть использованы для входного контроля качества растительных АФИ инулина как для подтверждения структуры, так и с целью определения чистоты субстанции. Результаты изучения физико-химических характеристик растительных АФИ инулина могут быть использованы при разработке национальной нормативной документации на субстанцию инулин.

Ключевые слова: инулин; описание; растворимость; гигроскопичность; микроскопия; идентификация; контроль качества

\section{STATEMENT OF THE PROBLEM}

One of the valuable API having a high biological activity and a specific effect on the organism is the polysaccharide inulin. It has found its application for stabilizing therapeutic proteins, enhancing dissolution of lipophilic drugs, as a filler of tablets, in the form of methacrylate hydrogels for transporting biologically active compounds to the distal segments of the gastrointestinal tract [1]. Inulin is also used as a diagnostic agent in determining the glomerular filtration rate in renal diseases. In addition, this polysaccharide has a prebiotic effect (stimulates the growth and the metabolic activity of bifidobacteria), affects the metabolism of carbohydrates and lipids, participates in the process of elimination of salts of heavy metals, etc., from the body $[2,3]$.

Inulin is a polyfructose chain, in which the molecules of fructose are connected to the $\beta-(2 \rightarrow 1)$ - glycoside bond, usually there is also one molecule of glucose connected with $a$-D-glucopyranosyl bond (Fig. 1) [1, 4-6].

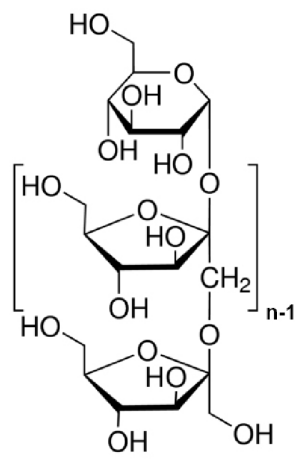

Fig. 1 The chemical structure of inulin (GFn, $n=2-60$ ) where G corresponds to the glucosyl part, F-is the fructosyl part, and $n$ - is the degree of polymerization 
THE QUALITY REQUIREMENTS FOR PLANT API OF INULIN BY THE MONOGRAPHS “INULIN" ACCORDING TO THE BRITISH AND UNITED STATES PHARMACOPEIAS

\begin{tabular}{|c|c|c|}
\hline Parameters & $\mathrm{BP}$ & USP \\
\hline \multicolumn{3}{|c|}{ Description } \\
\hline Appearance & An amorphous, granular, white powder & $\begin{array}{l}\text { An amorphous, odorless, white powder, } \\
\text { friable like chalk }\end{array}$ \\
\hline \multicolumn{3}{|c|}{ Properties } \\
\hline Hygroscopy & Hygroscopic & - \\
\hline Solubility & $\begin{array}{l}\text { Sparingly soluble in water; readily soluble } \\
\text { in hot water; sparingly soluble in organic } \\
\text { solvents }\end{array}$ & $\begin{array}{l}\text { Soluble in hot water; sparingly soluble in } \\
\text { cold water and in organic solvents }\end{array}$ \\
\hline Microscopy & $\begin{array}{l}\text { When studying in absolute ethanol it looks } \\
\text { like large, very irregular masses that are com- } \\
\text { pletely or partially fragmented, sometimes } \\
\text { with smaller spherical or ovoid particles }\end{array}$ & - \\
\hline \multicolumn{3}{|c|}{ Identification } \\
\hline $\begin{array}{l}\text { Seliwanoff's test } \\
\text { (a qualitative reaction for } \\
\text { keto group - fructose) }\end{array}$ & A red color must appear & - \\
\hline $\begin{array}{l}\text { The reaction with } \\
\text { Fehling's reagent } \\
\text { (a qualitative reaction for } \\
\text { aldehyde group) }\end{array}$ & $\begin{array}{l}\text { After hydrolysis of the substance to the } \\
\text { structural components - fructose and } \\
\text { glucose a red precipitate must appear }\end{array}$ & $\begin{array}{l}\text { The reaction is carried out without hydroly- } \\
\text { sis of the substance to confirm the absence of } \\
\text { reduced sugars. } \\
\text { The reaction does not proceed at room tem- } \\
\text { perature, a slight reaction maybe in } 1 \text { min of } \\
\text { boiling }\end{array}$ \\
\hline
\end{tabular}

The properties of inulin depend primarily on the degree of polymerization (DP), i.e. the number of monomeric fructose links in the polysaccharide macromolecule. The length of the fructose chain of the plant inulin varies from 2 to 60 . Under the action of acids and specific enzymes fructan can be hydrolyzed to the structural monomers $[1,6]$.

A high-molecular inulin, which number of fructose residues is more than 10 , is of interest for use in medical practice since its pharmacological activity is higher [7].

The raw material base for obtaining fructan has been significantly extended; its largest amount is stored in representatives of Asteraceae, Liliaceae and Poaceae families [5, 7, 8].

However, a significant number of plant sources and variability of production conditions determine the presence of substances of the polysaccharide at the market today; they differ in the number of fructose residues, the degree of purification from impurities, and by their physicochemical properties.

\section{ANALYSIS OF RECENT RESEARCHES AND PUBLICATIONS}

The description of physicochemical properties of API of inulin is given in the works of many researchers. Thus, according to the literature sources, inulin is an amorphous, granular, hygroscopic, practically odorless white powder, under the microscope it has the appearance of ribbed irregular particles, does not reduce Fehling's reagent. It is poorly solu- ble in cold water and readily soluble in hot water. Depending on the method of obtaining and polyfructan as the starting material it can be in the form of an amorphous powder and in the form of crystals $[2,3,5,9]$.

Pharmacopoeial requirements for the quality control of inulin are presented in the monographs "Inulin" of the BP and USP (Tab. 1) [10, 11]. In the State Pharmacopeia of Ukraine (SPhU) the appropriate normative documents for the substance of inulin are absent.

\section{IDENTIFICATION OF ASPECTS OF THE \\ PROBLEM UNSOLVED PREVIOUSLY}

The primary task of quality control of the substances to be analyzed in standardization is to identify a compound and study its critical characteristics. The particle size and morphology, hygroscopicity, and solubility of substances are incomplete list of indicators that determine the physicochemical and technological properties of substances, and this, in turn, is directly related to bioavailability and efficacy of the finished drug, its safety and stability when using [5-9].

Therefore, determination of the physicochemical characteristics of API of inulin and its identification are the initial, but not the less important stage of the input quality control of the object to be analyzed, it allows, if necessary, either to detect adulteration or to prove the quality of the substance. 


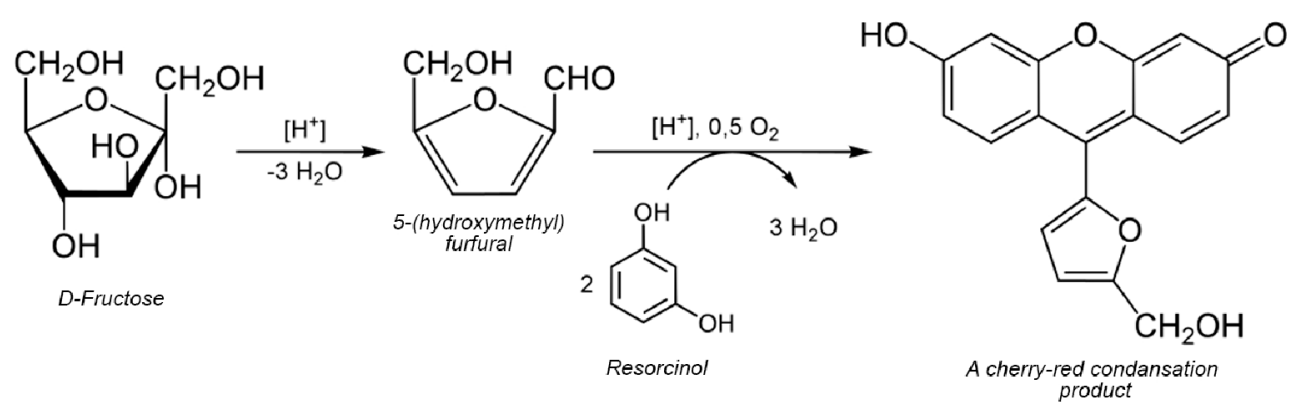

Fig. 2 The chemistry of the reaction of identification B (Seliwanoff's test)

OBJECTIVE STATEMENT OF THE ARTICLE

The aim of this fragment of complex studies is the quality control of plant API of inulin in accordance with the requirements of modern normative documents by such physicochemical characteristics as "Description", "Solubility", "Hygroscopy", "Microscopy", as well as identification of the structural components of fructan in order to involve the data obtained in development of the national normative documents on the substance of inulin.

\section{PRESENTATION OF THE MAIN}

\section{MATERIAL OF THE RESEARCH}

As the study objects the API of inulin were chosen from such plant sources as chicory (batch $01,04,05,06,07,09$ ), agave (batch 02,08 ) and Jerusalem artichoke (batch 03 ). The physicochemical characteristics of standard substances of inulin with chicory (batch 10; Sigma-Aldrich, PN: I2255, BN: SLBQ7169V) and with dahlia (batch 11; Sigma-Aldrich, PN: I3754, BN: SLBN1201V) were also taken into account.

The analysis of the objects was carried out in accordance with the requirements of the BP and USP by the following parameters: "Description," "Hygroscopy", "Microscopy", "Solubility in water $R$, in hot water $R$, in organic solvents" and by chemical reactions of identification: the reaction with copper tartrate reagent (Fehling's reagent) and with the alcoholic solution of resorcinol (Seliwanoff's test). The comparative characteristics of requirements regarding the quality of API of inulin according to these pharmacopoeias are given in Tab. 1 .

The solubility and the degree of hygroscopicity of the substances were studied according to the re- quirements of the monograph of the State Pharmacopeia of Ukraine (SPhU, 5.11) [12]. The solubility of substances was studied in water $R$, in hot water $R$ $\left(80-90^{\circ} \mathrm{C}\right.$ ) and in organic solvents (chloroform $R$ ). Determination of the degree of hygroscopicity was assessed in 24 hours, keeping the substances over the saturated solution of ammonium chloride.

The morphological characteristics (shape and size of the powder) for all API of inulin was studied by the method of microscopy according to the SPhU, 2.9.37, using an "Opton" microscope by "West Germany" company (the magnification range $-\mathrm{x} 100-\mathrm{x} 200$ ). On a glass slide a small amount of the substance powder uniformly distributing on the surface was placed (approximately $0.01 \mathrm{~g}$ ) in the mixture with ethanol (96\%) $R[12]$.

Identification of inulin was carried out according to the methods of the BP and USP:

Identification $B(B P)$. Dissolve $10 \mathrm{mg}$ of the substance in $2 \mathrm{ml}$ of hot water R, add $3 \mathrm{ml}$ of $0.15 \%$ alcoholic solution of resorcinol, then $3 \mathrm{ml}$ of hydrochloric acid $\mathrm{R}$, mix and heat at $80{ }^{\circ} \mathrm{C}$. A red color must appear (Fig. 2).

Preparation of $0.15 \%$ alcoholic solution of resorcinol: place $0.15 \mathrm{~g}$ of resorcinol $R$ in a $100 \mathrm{ml}$ volumetric flask, add a small amount of ethanol $R$ (96\%), dilute to the volume with the same solvent, and mix [11].

Identification $C(B P)$. Boil $5 \mathrm{ml}$ of $10 \%$ aqueous solution of inulin with $0.5 \mathrm{ml}$ of hydrochloric acid $R$ for $2 \mathrm{~min}$, cool and neutralize with sodium hydroxide solution $R$ by litmus paper. Add $0.5 \mathrm{ml}$ of copper tartrate solution $R 1$ prepared according to the requirements of the BP. A red precipitate must appear (Fig. 3).

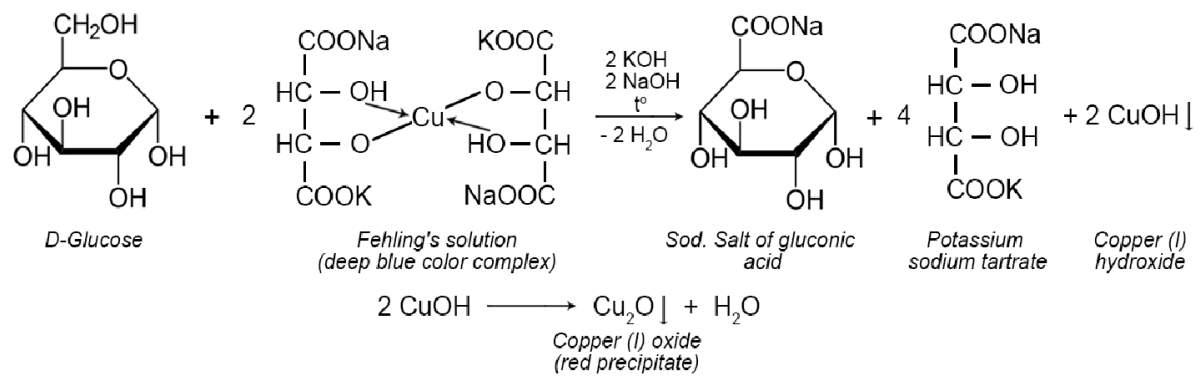

Fig. 3 The chemistry of the reaction of identification C (reaction with Fehling's reagent) 
CHARACTERISTICS OF THE STUDY OBJECTS

\begin{tabular}{|c|c|}
\hline Batch No. & Description \\
\hline 01 & $\begin{array}{l}\text { A loose, amorphous, odorless, white } \\
\text { powder }\end{array}$ \\
\hline 02 & $\begin{array}{l}\text { A loose, amorphous, odorless, pale } \\
\text { yellow powder }\end{array}$ \\
\hline 03 & $\begin{array}{l}\text { A loose, amorphous, odorless, } \\
\text { practically white powder }\end{array}$ \\
\hline 04 & $\begin{array}{l}\text { A loose, amorphous, odorless, white } \\
\text { powder }\end{array}$ \\
\hline 05 & $\begin{array}{l}\text { A loose, amorphous, odorless, pale } \\
\text { yellow powder }\end{array}$ \\
\hline 06 & $\begin{array}{l}\text { A loose, amorphous, odorless, white } \\
\text { powder }\end{array}$ \\
\hline 07 & $\begin{array}{l}\text { A loose, amorphous, odorless, white } \\
\text { powder }\end{array}$ \\
\hline 08 & $\begin{array}{l}\text { A loose, amorphous, odorless, } \\
\text { practically white powder }\end{array}$ \\
\hline 09 & $\begin{array}{l}\text { A loose, amorphous, odorless, white } \\
\text { powder }\end{array}$ \\
\hline $\begin{array}{c}10 \text { (Standard } \\
\text { substance of inulin } \\
\text { with chicory) } \\
\end{array}$ & $\begin{array}{l}\text { A loose, amorphous, odorless, white } \\
\text { powder, friable like chalk }\end{array}$ \\
\hline $\begin{array}{c}11 \text { (Standard } \\
\text { substance of inulin } \\
\text { with dahlia) }\end{array}$ & $\begin{array}{l}\text { A loose, amorphous, odorless, white } \\
\text { powder, friable like chalk }\end{array}$ \\
\hline
\end{tabular}

Preparation of copper tartrate solution R1 (by the requirements of the $B P$ ):

Solution A. Dissolve $34.6 \mathrm{~g}$ of copper (II) sulfate $R$ in the mixture of $0.5 \mathrm{ml}$ of sulfuric acid $R$ and water $R$, dilute the solution to the volume of $500 \mathrm{ml}$.

Solution B. Dissolve $176 \mathrm{~g}$ of potassium sodium tartrate $R$ and $77 \mathrm{~g}$ of sodium hydroxide $R$ in water $R$, dilute the solution to the volume of $500 \mathrm{ml}$ with the same solvent.

Mix the equal volumes of solutions A and B immediately before use [11].

Identification (USP). Dissolve $10.0 \mathrm{~g}$ of inulin in $20 \mathrm{ml}$ of hot water $R$ in a $100 \mathrm{ml}$ volumetric flask, cool, dilute the solution to the volume with water $R$ and mix (solution S). To $2 \mathrm{ml}$ of solution $S$ add $5 \mathrm{ml}$ of copper tartrate solution prepared according to the requirements of the USP: the reaction does not proceed at room temperature, a slight reaction maybe in 1 min of boiling (Fig. 3).

Preparation of copper tartrate solution (by the requirements of the USP):

Solution A. Dissolve $34.6 \mathrm{~g}$ of copper (II) sulfate $R$ in water $R$, dilute the solution to the volume of $500 \mathrm{ml}$ with the same solvent.

Solution B. Dissolve $173 \mathrm{~g}$ of potassium sodium tartrate $R$ and 50 of sodium hydroxide $R$ in $400 \mathrm{ml}$ of water $R$. Heat to boiling, cool, dilute the solution obtained to the volume of $500 \mathrm{ml}$ with water $R$ that is free of carbon dioxide.
THE DEGREE OF HYGROSCOPY

\begin{tabular}{|c|c|c|}
\hline Batch No. & $\begin{array}{c}\text { The degree of } \\
\text { hygroscopy, } \%\end{array}$ & Compliance \\
\hline 01 & $14.31 \pm 0.01$ & Hygroscopic \\
\hline 02 & $15.94 \pm 0.29$ & Very hygroscopic \\
\hline 03 & $14.54 \pm 0.04$ & Hygroscopic \\
\hline 04 & $21.19 \pm 0.05$ & Very hygroscopic \\
\hline 05 & $16.03 \pm 0.12$ & Very hygroscopic \\
\hline 06 & $15.11 \pm 0.21$ & Very hygroscopic \\
\hline 07 & $11.41 \pm 0.07$ & Hygroscopic \\
\hline 08 & $9.40 \pm 0.23$ & Hygroscopic \\
\hline 09 & $11.09 \pm 0.24$ & Hygroscopic \\
\hline $\begin{array}{c}10 \text { (Standard } \\
\text { substance of } \text { inulin } \\
\text { with chicory) }\end{array}$ & $12.10 \pm 0.10$ & Hygroscopic \\
\hline $\begin{array}{c}11 \text { (Standard } \\
\text { substance of } \text { inulin } \\
\text { with dahlia) }\end{array}$ & $11.90 \pm 0.17$ & Hygroscopic \\
\hline
\end{tabular}

Mix the equal volumes of solutions A and B immediately before use [10].

The reagents used in the analysis meet the requirements of the SPhU. All tests were performed in several replicates.

According to the BP when carrying out chemical reactions of identification the substances of inulin studied (batches 01-09) and standard substances of inulin with chicory and dahlia (batches 10,11) had a red color in Seliwanoff's test (identification B), confirming the presence of fructose, and an orangered / dark-red precipitate in the reaction with $\mathrm{Fe}$ hling's reagent after hydrolysis (identification C), indicating the presence of glucose.

According to the USP [10] by the reaction with copper tartrate reagent performed without prior hydrolysis of the substances the reaction did not proceed at room temperature, however, when heated for 1 min the appearance of an orange-red precipitate in the compounds analyzed was observed (batches 1-9). This indicates the presence of sugars with the properties of reducing agents in the substances studied and requires further research. In the samples of batches 10, 11 a blue coloration after heating did not change.

In the experiment it has been found that the API of inulin studied (batches 01-09) and the standard substances of inulin with chicory and dahlia (batches 10,11) are loose, amorphous, powders of white, practically white and pale yellow color by the "Description" $[10,11]$ parameter (Tab. 2).

According to Tab. 3 the test samples are hygroscopic (increase in mass is from $2 \%$ to $15 \%$ ) and very hygroscopic (increase in mass is more than $15 \%)$.

By the parameters of "Solubility" [11] in water $R$ (the temperature was $25^{\circ} \mathrm{C}$ ) the substances analyzed 


\section{SOLUBILITY OF API OF INULIN}

\begin{tabular}{|c|c|c|c|}
\hline \multirow{2}{*}{ Batch No. } & $\begin{array}{c}\text { In water } \\
\left(\text { at } 25^{\circ} \mathrm{C}\right)\end{array}$ & $\begin{array}{c}\text { In hot water } \\
\left(\text { at } 90^{\circ} \mathrm{C}\right)\end{array}$ & In organic solvents \\
\cline { 2 - 3 } & Slightly soluble & Readily soluble & \multirow{2}{*}{} \\
\hline 01 & Soluble & Very soluble \\
\hline 02 & Readily soluble & Readily soluble \\
\hline 03 & Soluble & Very soluble \\
\hline 04 & Readily soluble & Very soluble \\
\hline 06 & Slightly soluble & Readily soluble & \multirow{2}{*}{ Insoluble } \\
\hline 07 & Soluble & Readily soluble \\
\hline 08 & Readily soluble & Very soluble \\
\hline 09 & Slightly soluble & Readily soluble \\
\hline $\begin{array}{c}10 \text { (Standard substance } \\
\text { of inulin with chicory) }\end{array}$ & Slightly soluble & Readily soluble \\
\hline $\begin{array}{c}11 \text { (Standard substance } \\
\text { of inulin with dahlia) }\end{array}$ & Practically insoluble & Readily soluble \\
\hline
\end{tabular}

were readily soluble, soluble and sparingly soluble in water $R$, while by the solubility in hot water $R$ (its temperature was $80-90{ }^{\circ} \mathrm{C}$ ) all samples were very soluble or readily soluble (Tab. 4).

It is known from the literature sources that the less the number of fructose residues in the inulin structure is, the greater is the solubility of the substance $[1,2,4]$. In this regard, high parameters of solubility in water at the temperature of $25^{\circ} \mathrm{C}$ indicate the potential presence of low molecular weight inulin fractions in the test samples.

The solubility of substances was also checked in chloroform $R$. It has been experimentally confirmed that in chloroform $R$ all samples are insoluble.

The next step was to study the structure of plant API of inulin by the method of microscopy

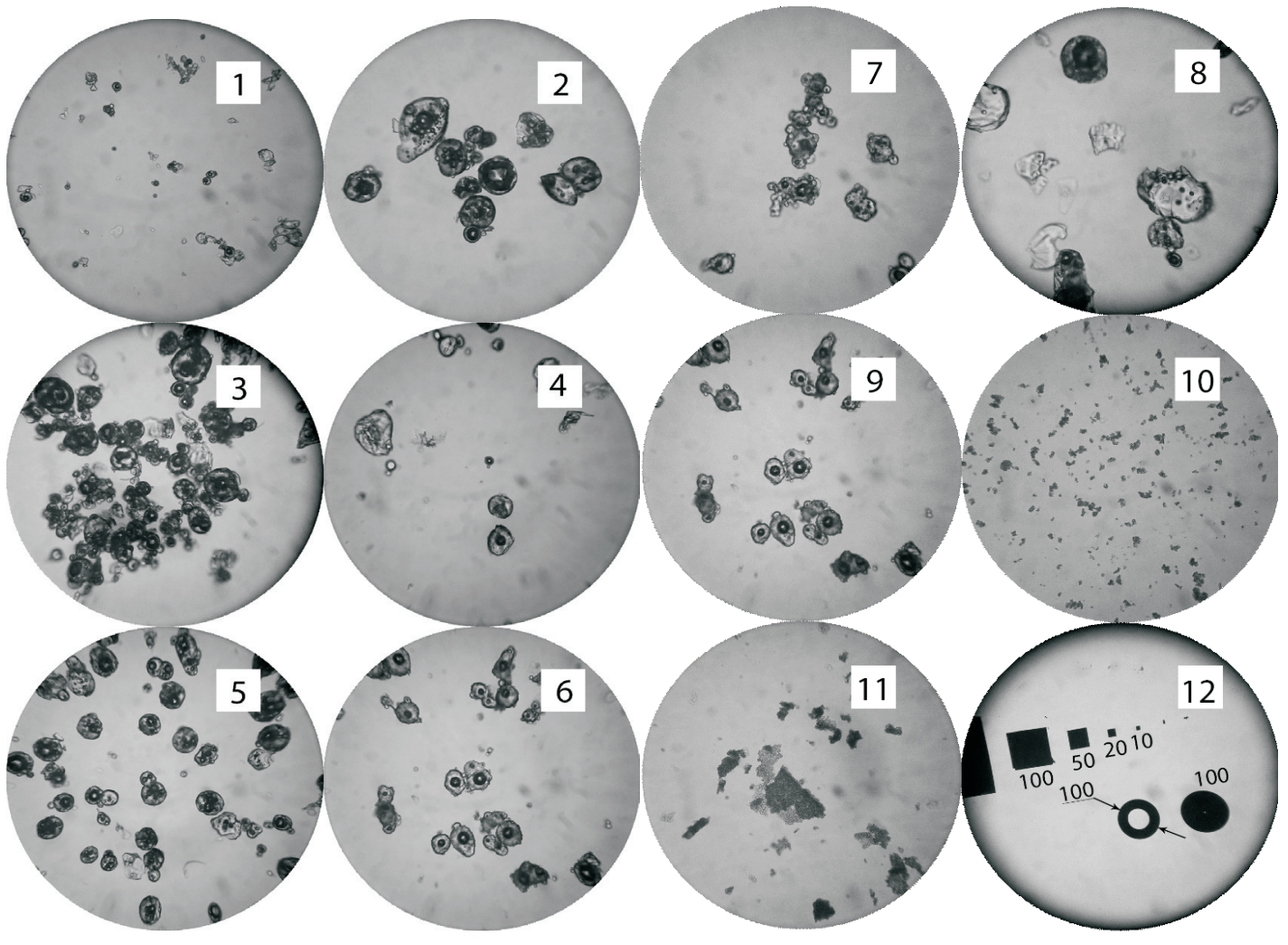

Fig. 4 The photomicrographs of API of inulin in ethanol (96\%) $R$ obtained with a light microscope in 200-fold magnification: the substances of inulin of batch 01-09 (1-9); standard substance of inulin with chicory (10); standard substance of inulin with dahlia (11); a calibrated stage micrometer (12) 
in ethanol (96\%) $R$ [11]. The photomicrography is given in Fig. 4.

The study of morphology of API of inulin by light microscopy shows that the samples (batches 02-09) look like masses with large spherical or ovoid particles that are completely or partially fragmented. As noted in the works [2], these formations can be described as pseudomorphic or pseudocrystalline with the expressed central micelles looking like black cores and peripheral semi-transparent shells, as well as small parts of inulin (in the form of dark points) separated from the main pseudocrystalline formations.

The samples of batches $01,10,11$ in this magnification are also completely or partially fragmented spherical or ovoid particles; however, the substances have a smaller size due to the greater degree of fineness.

\section{CONCLUSIONS AND PROSPECTS FOR FURTHER RESEARCH}

1. According to the BP the presence of the structural components - fructose and glucose after hydrolysis of the main substance can be con- firmed by the chemical reactions of identification of plant API of inulin. According to the USP the identification reaction can confirm the presence of inulin as a substance that does not reduce Fehling's reagent, as well as determine the presence of impurities of sugars with the properties of reducing agents.

2. The results of studying the physicochemical characteristics of plant API of inulin according to such parameters as "Appearance", "Solubility", "Hygroscopy", "Microscopy" can be used for the input quality control of API of inulin to confirm the structure and determine the purity of the substance.

3. The results of studying the physicochemical characteristics of plant API of inulin can be used when developing the national normative documents on the substance of inulin.

Conflict of Interests: authors have no conflict of interests to declare.

ABBREVIATIONS

API, plant active pharmaceutical ingredients; BP, the British Pharmacopoeia; USP, the United States Pharmacopeia.

\section{REFERENCES}

1. Inulin, a flexible oligosaccharide I : Review of its hysicochemical characteristics / M. A. Mensink, H. W. Frijlink, K. van der Voort Maarschalk, W. L. Hinrichs // Carbohydrate Polymers. - 2015. - Vol. 130. - P. 405-419. doi: 10.1016/j.carbpol.2015.05.026

2. Морфологические, структурные и дегидратационные свойства инулина «Raftilin GR» / В. В. Литвяк, Н. Д. Лукин, А. А. Михайленко, А. В. Канарский // Вестник Казанского технологического университета. - 2015. - № 18 (1). - С. 94-99.

3. Öztürk, B. A rising star prebiotic dietary fiber : Inulin and recent applications in meat products / B. Öztürk // J. Food Health Sci. - 2016. - P. 12-20. doi: 10.3153/jfhs17002

4. Physical properties of inulin and inulin-orange juice : physical characterization and technological application / M. Z. Saavedra-Leos, C. Leyva-Porras, E. Martínez-Guerra et al. // Carbohydrate Polymers. - 2004. - Vol. 105. - P. 10-19. doi: 10.1016/j.carbpol.2013.12.079

5. Roberfroid, M. B. Inulin-type fructans : functional food ingredients / M. B. Roberfroid // The J. of Nutrition. - 2007. - Vol. 137, Issue 11. - P. 2493S-2502S. doi: 10.1093/jn/137.11.2493s

6. Kriukova, Y. Chain length distribution of inulin from dahlia tubers as influenced by the extraction method / Y. Kriukova // Intern. J. of Food Properties. - 2018. - P. 1-11.

7. Криворук, В. М. Фізико-хімічні і функціонально-технологічні властивості інуліну з топінамбуру / В. М. Криворук, К. А. Каліннік, М. О. Шульц // Молодий вчений. - 2015. - № 12 (27). - Ч. 1. - С. $52-55$.

8. Євтіфєєва, О. А. Актуальність розробки та впровадження монографії «Інулін» до Державної фармакопеї України / О. А. Євтіфєєва, Н. М. Смєлова // Теоретичні та практичні аспекти дослідження лікарських рослин : матеріали II Міжнародної наук.-практ. internet-конф. (м. Харків, 21-23 березня 2016 р.) / ред. кол. : Т. М. Гонтова, А. О. Мінаєва, Н. І. Ільїнська. - Х. : НФаУ, 2016. - С. 106-108.

9. Franck, A. Technological functionality of inulin and oligofructose / A. Franck // British J. of Nutrition. Vol. 87, Issue S2. - 2002. - S287 p. doi: 10.1079/bjn/2002550

10. Pharmacopeia U. S. National Formulary (USP 36-NF 31) Online / United States Pharmacopeial Convention, 2013.

11. Pharmacopoeia B. British Pharmacopoeia. Medicinal and Pharmaceutical Substances. - London : The Stationery Office, 2010.

12. Державна фармакопея України : в 3 т. / Український науковий фармакопейний центр якості лікарських засобів. - 2-е вид. - Х. : Український науковий фармакопейний центр якості лікарських засобів, 2015. - Т. 1. - 1128 с. 


\section{REFERENCES}

1. Mensink, M. A., Frijlink, H. W., van der Voort Maarschalk, K., Hinrichs, W. L. J. (2015). Inulin, a flexible oligosaccharide I: Review of its physicochemical characteristics. Carbohydrate Polymers, 130, 405-419. doi: 10.1016/j.carbpol.2015.05.026

2. Litviak, V. V., Lukin, N. D., Mikhailenko, A. A., Kanarskii, A. V. (2015). Vestnik Kazanskogo tekhnologicheskogo universiteta, 18 (1), 94-99.

3. Öztürk, B. (2016). A rising star prebiotic dietary fiber: inulin and recent applications in meat products. Journal of Food and Health Science, 12-20. doi: 10.3153/jfhs 17002

4. Saavedra-Leos, M. Z., Leyva-Porras, C., Martínez-Guerra, E., Pérez-García, S. A., Aguilar-Martínez, J. A., Álvarez-Salas, C. (2014). Physical properties of inulin and inulin-orange juice: Physical characterization and technological application. Carbohydrate Polymers, 105, 10-19. doi: 10.1016/j.carbpol.2013.12.079

5. Roberfroid, M. B. (2007). Inulin-Type Fructans: Functional Food Ingredients. The Journal of Nutrition, 137 (11), 2493S-2502S. doi: 10.1093/jn/137.11.2493s

6. Kriukova, Y. (2018). Chain length distribution of inulin from dahlia tubers as influenced by the extraction method. International Journal of Food Properties, 1-11.

7. Kryvoruk, V. M., Kalinnik, K. A., Shults, M. O. (2015). Molodyi vchenyi, 12 (27), 1, 52-55.

8. Yevtifieieva, O. A., Smielova, N. M. (2016). Teoretychni ta praktychni aspekty doslidzhennia likarskykh roslyn, 106-108.

9. Franck, A. (2002). Technological functionality of inulin and oligofructose. British Journal of Nutrition, 87 (S2), S287. doi: 10.1079/bjn/2002550

10. Pharmacopeia U. S. National Formulary (USP 36-NF 31) Online (2013). United States Pharmacopeial Convention.

11. Pharmacopoeia B. British Pharmacopoeia. Medicinal and pharmaceutical substances. (2010). London: The Stationery Office.

12. Derzhavna Farmakopeia Ukrainy : v 3 t. (2015). Kharkiv: Ukrainskyi naukovyi farmakopeinyi tsentr yakosti likarskykh zasobiv, 1, 1128.

Адреса для листування:

Надійшла до редакції 14.03.2018 p

61168, м. Харків, вул. Валентинівська, 4.

E-mail: smelova08@gmail.com.

Національний фармацевтичний університет

Смєлова H.M. (ORCID - https://orcid.org/0000-0001-5878-5072)

Євтіфєєва O.A. (ORCID - http://orcid.org/0000-0002-0322-7054)

Губарь C.M. (ORCID - http://orcid.org/0000-0002-5434-9502) 